\title{
Хавкин Б. Л. Россия и Германия. 1900-1945. Сплетение истории. М.: Новый хронограф, 2014. 424 с.
}

\begin{abstract}
Аннотаиия: Рецензия на новую книгу известного отечественного историка Бориса Львовича Хавкина, посвященную наиболее ярким персонажам и странииам российско-германской истории XX в. Анализируются исторические портреты А. Парвуса (Гельфанда), У. Брокдорф-Раниау, В. Мирбаха, В. Шуленбурга, Ф. Паулюса, Э. фон Клейста, Ф. Шернера и других. Дана характеристика историческим изысканиям автора по таким спорным и актуальным вопросам, как роль Германии в подготовке большевистского переворота 1917 г., советско-германский пакт 1939 г., деятельность «Красной капелль» и т. д. В рещензии критическому анализу подвергнут ряд кониептуальных положений рещензируемого исследования по общим аспектам российскогерманской истории XX в. В иентре внимания речензента находятся исторические персонажи и события, которые объединили историю России и Германии начиная с 1917 г. и заканчивал 1945 г. Рецензируемое издание выполнено на высоком научном уровне, снабжено публикаииями источников и фотодокументов и представляет несомненный интерес для специалистов в области российско-германских отношений, а также всех интересуюшихся историей.
\end{abstract}

Ключевые слова: история России, история Германии, российско-германские отношения, Брестский мир, «политика Рапалло», начионал-соииализм, большевизм, Великая Отечественная война, движение Сопротивления, Вторая мировая война.

Annotation: The article is a review of the new book by the famous Russian historian Boris Lvovich Havkin dealing with the most illustrious figures and events in the Russo-German history of the 20th century. The publication analyses the historical portraits of Alexander Parvus (Helphand), Ulrich von Brockdorff-Rantzau, Wilhelm von Mirbach-Harff, Friedrich-Werner Graf von der Schulenburg, Friedrich Wilhelm Paulus, Ewald von Kleist, Ferdinand Sch rner and others. The review gives a description of the theses written by the book's author on such current and contested questions as the role of Germany in the preparation of the Bolshevik overturn of 1917, the Soviet-German pact of 1939, the activities of the "Red chapel", etc. A series of conceptual positions of the reviewed study are subjected to a critical analysis, concerning the general aspects of the Russo-German history of the 20th century. At the reviewer's centre of attention lie the historical figures and events, which united the histories of Russia and Germany since 1917 up to 1945. The reviewed volume is of the highest scientific quality, furnished with source publication and photographic documents, and is of unquestionable interest for specialists in the field of Russo-German relations, as well as for those interested in history in general.

Key words: Russian history, German history, Russo-German relations, 1918 Treaty of Brest, "Rapallo policy", National socialism, Bolshevism, Great Patriotic War, Resistance movement, Second World War.

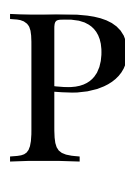
оссийско-германские отношения в очередной раз переживают непростые времена. В этих условиях актуальной представляется новая книга известного российского историка Бориса Львовича Хавкина, основной акцент в которой сделан на сплетении истории двух стран и народов. Автор даже отмечает, что за первую половину XX в. сложилась некая общая «российско-германская история» (c. 7). В наибольшей степени это можно проследить на примере таких событий, как Первая мировая война и революции 1917-1919 гг. в Рос- сии и Германии, советско-германские контакты и взаимодействие периода Веймарской республики и национал-социализма, Великой Отечественной войны. Эти и другие ключевые точки российско-германской истории показаны автором через отдельные исторические персонажи, чья деятельность оказалась определяющей как для России, так и для Германии.

С этой точки зрения выбор Александра Парвуса, «сутенера империализма», в качестве объекта первой главы понятен и закономерен. Именно его фигура стояла за финансовыми и 


\section{Рецензии, библиография}

DOI: $10.7256 / 2222-1972.2014 .5 .14672$

организационными инвестициями в русскую революцию со стороны Германии в 1917 г. Автор, в т. ч. и на основе неизвестных ранее архивных материалов, показывает роль Парвуса в подготовке большевистского переворота. Однако большевики и В. И. Ленин лично не желали иметь ничего общего с Парвусом после победы. Ненужным стал он и для Германии, где тихо доживал свои дни и умер в один год с Лениным (с. 36-37).

После того как большевики, в том числе и при помощи Парвуса, пришли к власти, их главной задачей стало сохранение своей диктатуры. Фактическая капитуляция перед Германией по Брестскому миру сделала новых правителей России настолько непопулярными, что от них отвернулись даже вчерашние союзники - левые әсеры. И здесь российско-германская история переплелась в судьбе еще одной видной личности - графа Мирбаха. Историческому расследованию его убийства посвящена вторая глава рецензируемой книги.

Б. Л. Хавкин справедливо отмечает, что германский посол в Советской России Мирбах «стал заложником, с одной стороны, политики вынужденного партнерства рейха с большевиками, с другой - поисков политических альтернатив правительству Ленина» (с. 39). Именно вождь большевиков, по мнению автора, больше всех выиграл от смерти Мирбаха, знавшего слишком много. Неслучайно его непосредственные убийцы (Н. Андреев и Я. Блюмкин) так и не понесли заслуженного наказания.

Убийство графа Мирбаха не привело к возобновлению войны России и Германии. Более того, курс на сотрудничество двух стран был сохранен и продолжен и руководством Веймарской республики. В 1922 г. был заключен известный российско-германский договор в Рапалло, который открыл новую страницу в истории взаимодействия двух стран. Важнейшим персонажем здесь стал новый посол Германии в Москве граф У. Брокдорф-Ранцау. Ему Б. Л. Хавкин посвятил третью главу своего исследования.

Именно этот германский дипломат в 1915 г. сделал ставку на использование Парвуса (Гельфанда) для подготовки революции в России. Он был настроен весьма скептически относительно союза с Советской Россией. Убийство Мирбаха было как раз одним из доводов в пользу того, что большевикам нельзя доверять. Став в ноябре 1922 г. послом в Москве, Ранцау предлагал придерживаться формулы Парвуса: «Политические перемены на основе экономического сбли- жения» (с. 75). При этом германский дипломат продолжал поддерживать с Парвусом отношения вплоть до смерти последнего.

«Последний бисмаркианец» в течение шести лет возглавлял германское диппредставительство в Стране Советов и оставил о себе хорошую память. Об этом свидетельствовал некролог на смерть Ранцау, написанный Михаилом Кольцовым, в котором указывалось, что «этот граф понял и никогда не забывал, что Советский Союз, какими бы глазами ни смотрели на это, могучая держава, с которой надо стараться жить в дружбе и согласии» (с. 82).

На протяжении 1920-х - начала 1930-х гг. советско-германские отношения развивались на принципах взаимовыгодного сотрудничества. Их кардинальный пересмотр произошел после прихода нацистов к власти в Германии. В очередной главе своей книги Б. Л. Хавкин останавливается на наиболее знаковом событии в истории германо-российской истории первой половины XXв., а именно - на истории публикации советских официальных текстов советскогерманских документов 1939 г.

В течение полувека власти СССР скрывали сам факт существования оригиналов секретных протоколов к советско-германскому пакту о ненападении. И лишь накануне распада Советского Союза они были опубликованы. Автор подчеркивает, что произошло это в силу политических причин и было связано с победой Б. Н. Ельцина в борьбе за власть (с. 85). А сама публикация в журнале «Новая и новейшая история» была осуществлена как раз автором рецензируемого исследования - Б. Л. Хавкиным [2, 83-95].

Еще одним важным историческим свидетельством, долгое время скрытым в советских архивах, были письма лидера германских коммунистов Әрнста Тельмана за 1939-1941 гг. из германской тюрьмы к И. В. Сталину и В. М. Молотову. Тельман рассчитывал, что после заключения пакта Молотова-Риббентропа руководители СССР добьются его освобождения, но этого не произошло. Из приведенных писем нельзя получить однозначный ответ на вопрос о том, почему Тельман так и остался в застенках гестапо. Видимо, историкам еще предстоит подискутировать по этому поводу.

История Второй мировой войны до сих пор полна загадок и неоднозначно трактуемых событий. Б. Л. Хавкин останавливается на одном из них - истории «Красной капеллы». И вновь на помощь приходят архивные материа- 


\section{Исторический журнал: научные исследования № 5 (23) • 2014}

DOI: 10.7256/2222-1972.2014.5.14672

лы и документы, обнаруженные автором в конце XX - начале XXI вв. В данном случае - в Архиве Президента РФ и Архиве ФСБ РФ.

Б. Л. Хавкин подчеркивает, что «Красная капелла» сыграла важную роль в германском Сoпротивлении, хотя и не подтверждает принятое в историографии мнение об этой организации как о самой большой советской разведывательной сети периода Великой Отечественной войны (с. 183). Продолжая перекличку с другими главами своего исследования, автор акцентирует внимание на том, что активную помощь подпольщикам оказывала семья Брокдорф-Ранцау, в квартире которой хранилась рация подпольщиков (с. 202).

Продолжая тему германского Сопротивления, Б. Л. Хавкин обращается к историческим прототипам легендарного киногероя Штирлица. Автор обоснованно и аргументированно доказывает, что в реальности внедренного советского разведчика такого уровня просто не могло существовать. Для этого необходимо было документально подтвердить «арийское» происхождение с 1750 г., иметь характеристики и рекомендации от местной ячейки НСДАП, быть женатым на «чистокровной арийке», постоянно проживать в одном месте не менее пяти лет и т. п. (с. 226-227). Тем не менее у вымышленного Исаева-Штирлица есть исторический прототип - немецкий полицейский чиновник-криминалист Вилли Леман.

Добродушный «дядюшка Вилли», как называли его за глаза в гестапо, был единственным высокопоставленным нацистским офицером, сотрудничавшим с советскими спецслужбами. Он поставлял действительно важную информацию. Именно он вечером 19 июня 1941 г. сообщил о скором начале войны. На счету Лемана был еще целый ряд важных сообщений, которые помогли советской стороне в годы войны. К сожалению, в декабре 1942 г. он был разоблачен и расстрелян (с. 250).

Важную роль в немецком Сопротивлении играли и некоторые видные политики и дипломаты, в частности граф Фридрих фон Шуленбург. Именно он, будучи послом в Москве, пытался спасти мир и не допустить войны с Советским Союзом. Автор отмечает, что граф Шуленбург был одной из наиболее значимых фигур в германской политической жизни, настроенных оппозиционно по отношению к Гитлеру. Он ратовал за сепаратный мир с Советским Союзом и поддержал заговор 20 июля 1944 г.
Шуленбург отрицал свое участие в заговоре, хотя и признавал, что общался с его организаторами. В итоге он был приговорен к смерти и повешен 10 ноября 1944 г. Б. Л. Хавкин приводит слова из политического завещания германского дипломата, обращенного к В. М. Молотову: «Я умер за дело, которому я посвятил свою жизнь в Москве, то есть за советско-германское сотрудничество» (с. 271).

Заговор 20 июля 1944 г. против Гитлера одна из центральных тем рецензируемого издания. Автор обращается к характеристике менее известных противников фюрера, таких как генерал Хеннинг фон Тресков и майор Иоахим Кун. Последний сыграл видную роль в подготовке покушения на Гитлера (он приобрел и прятал взрывчатку), будучи ближайшим соратником Штауфенберга и Трескова. В результате стечения обстоятельств Кун не был арестован нацистами, а попал в советский плен. 2 сентября 1944 г. он напечатал «Собственноручные показания майора Куна», которые являются ценнейшим источником по истории заговора 20 июля 1944 г. Этот документ Б. Л. Хавкин публикует на с. 318-357 своей книги. Что касается судьбы самого Куна, то в СССР он рассматривался как военный преступник и до 1956 г. находился в заключении. После освобождения он перебрался в ФРГ, где прожил до 1994 г., всеми забытый и брошенный (с. 317).

Б. Л. Хавкин справедливо замечает, что «долгое время история военного плена была “белым пятном" историографии Второй мировой войны» (с. 358). Это касалось не только таких персонажей, как Кун, но и германских военачальников, в частности маршалов. Их судьбу автор проанализировал в 11-й главе книги.

За годы войны в советский плен попали 376 генералов, включая трех генерал-фельдмаршалов: Ф. Паулюса, Э. фон Клейста и Ф. Шернера. Автор отмечает, что если история пребывания в плену Паулюса и Шернера достаточно неплохо освещена в историографии, то о судьбе Клейста известно значительно меньше. Связано это с неоднозначной ролью фельдмаршала в войне на Восточном фронте. Б. Л. Хавкин отмечает, что Клейст был одним из наиболее успешных гитлеровских военачальников. Он особо отличился в боях за Кубань и Крым.

Произведенный в феврале 1943 г. в фельдмаршалы, Клейст стремился привлечь к войне на стороне Германии коллаборационистов из числа местного населения Крыма и Кавказа: казаков, карачаевцев, кабардинцев, осетин, ин- 


\section{Рецензии, библиография}

DOI: $10.7256 / 2222-1972.2014 .5 .14672$

гушей, чеченцев, калмыков, грузин и других. В соответствии с расовой теорией горцы Кавказа считались «равноправными союзниками» гитлеровцев. Попутно Клейст практиковал «гуманное обращение» с населением оккупированных советских территорий. Причем даже таты (горские евреи) не подвергались при нем жестоким преследованиям; европейские евреи были уничтожены в первые дни оккупации (с. 384-385).

Клейст также был причастен к заговору 20 июля 1944 г., но в итоге был освобожден изпод ареста. В конце войны он был арестован американцами, которые выдали его властям социалистической Югославии. Там он был осужден на 15 лет за военные преступления и в 1949 г. выдан Советскому Союзу и осужден уже на 25 лет. В сентябре 1954 г. он умер во владимирской тюрьме.

Делая выводы, Б. Л. Хавкин отмечает, что все три германских фельдмаршала, попавшие в советский плен, совершали военные престу- пления. При этом один из них (Паулюс) избежал обвинений, Шернер был осужден, но ему смягчили приговор и отпустили в Западную Германию, и только Клейст был наказан по всей строгости.

В заключение Б. Л. Хавкин делает весьма неожиданный вывод: «Считается, что история чему-то учит. Принято учиться на ошибках прошлого, извлекать из них уроки. Смею усомниться в этой прописной истине: к сожалению, история, в частности $\mathrm{XX}$ век, учит только тому, что ничему не учит» (с. 407). Автор считает, что совместная российско-германская история лишь подтверждает эту закономерность. Тем не менее следует признать, что сама книга Б. Л. Хавкина является, несомненно, увлекательной и поучительной как для историков-профессионалов, так и для простого читателя, интересующегося современной историографией. Она продолжает цикл ярких исторических публикаций этого автора $[1,107 ; 3]$.

\section{Библиография:}

1. Кретинин С. В., Некрасова Т. А. Банальность зла // Родина. 2014. № 6. С. 107.

2. Советско-германские документы 1939-1941 гг. из архива ЦК КПСС // Новая и новейшая история. 1993. № 1. С. 83-95.

3. Хавкин Б. Л. Рейхсфюрер СС Гиммлер. Второй после Гитлера. М.: Алгоритм, 2014. 224 с.

\section{References (transliterated):}

1. Kretinin S. V., Nekrasova T. A. Banal'nost' zla // Rodina. 2014. № 6. S. 107.

2. Sovetsko-germanskie dokumenty 1939-1941 gg. iz arkhiva TsK KPSS // Novaya i noveishaya istoriya. 1993. № 1. S. 83-95.

3. Khavkin B. L. Reikhsfyurer SS Gimmler. Vtoroi posle Gitlera. M.: Algoritm, 2014. $224 \mathrm{~s}$. 